\title{
Special Issue: Crime, Fear of Crime and Environmental Harm in Rural Areas
}

\author{
Vania Ceccato ${ }^{1}\left({ }^{10} \cdot\right.$ Gorazd Meško $^{2}(]$
}

Accepted: 27 August 2021 / Published online: 8 September 2021

(c) The Author(s), under exclusive licence to Springer Nature Switzerland AG 2021

\section{Introduction}

Lower crime rates in rural areas are often taken as a sign that crime is not a major concern. Despite the fact that nearly half (45\%) of the world's population live in small communities and sparsely populated areas, issues of crime and safety are often neglected in these areas because crime is less frequent or considered less important when compared to safety issues in large urban areas. This is problematic because less crime in rural areas does not mean that crime is not a problem for people living there (Yarwood, 2001, p. 206) or that crime affects individuals and areas in the same way (Ceccato \& Dolmen, 2011). One of the reasons for this lack of attention to the nature of rural crime may be the widespread belief in a clear dichotomy between urban and rural, the former being criminogenic and unsafe, and the latter problem-free, idyllic, and healthier and friendlier (Barclay et al., 2004; Donnermeyer \& DeKeseredy, 2013). Another issue is the misconception that rural areas are homogenous in nature-a view that disregards their diversity not only geographically but also in terms of challenges they face (Wells \& Weisheit, 2004). This recognition is not particularly original but does reflect the negligence of issues outside the urban realm by different disciplines, including criminology.

Although rural criminology is a growing field of research (Harkness, 2020; Meško, 2020), the knowledge about 'ordinary' rural crimes in international contexts still remains incipient compared with other fields (but see Ceccato, 2015a, 2015b; Donnermeyer, 2016). If we extend the focus to account for events that are not defined by law as crimes

Vania Ceccato

vania.ceccato@abe.kth.se

1 Department of Urban Planning and Environment, KTH

Royal Institute of Technology, Stockholm, Sweden

2 Institute of Criminal Justice and Security, Faculty of Criminal Justice and Security, University of Maribor, Maribor, Slovenia but still cause harm (Hillyard \& Tombs, 2007) against wildlife, environment or people, then a variety of issues in need of further research emerges (e.g., Favarin, 2020; Stassen \& Ceccato, 2020; von Essen et al., 2014). The adoption of the concept of 'harm' enables us to move beyond legal definitions of 'crime' to include immoral, wrongful, and injurious acts that are not necessarily illegal but may lead to injury or damage to individuals or society, either intentionally or because of negligence. Animal abuse, animal rights extremism and ecoterrorism-activities that often take place in rural contexts-as well as traditional offenses, such as violence against women in rural contexts, constitute an emergent area of scientific inquiry that deserves greater international attention. Equally important is the nature of fear of crime in rural contexts. Fear is expected to be triggered by situational features typical of particular environments of the rural. Yet, individuals may declare feeling fearful for a variety of reasons, some of which may relate to the likelihood of being a victim of crime, while others are due to the nature of rural communities (Chakraborti \& Garland, 2011; DeKeseredy et al., 2007), or when negligence and poor management of public services may lead to a sense of "poor reassurance" (Wakefield \& Fleming, 2009).

In drawing together these themes, this special issue aims to address these gaps in knowledge by providing examples of studies of crime, harm, and fear of crime in rural areas in different international contexts with particular focus on 'new' types of offenses or 'new' types of harm. This special issue is composed of studies following rigorous analytical analysis to produce sound knowledge that can inform research, practice, and advise policy makers. Contributions to the special issue have relied on a wide range of theoretical traditions, from situational perspectives to critical criminology. We have welcomed contributions that adopt international and gender informed perspectives to the significance of rural crime. These studies reflect an interdisciplinary array of fields from Sociology, Criminology and Law (Pedersen and White; Eman and Meško), Psychology (Liu, Beier \& 
Vazsonyi; Strand, Selenius, Petersson \& Storey), Geography and Planning (Ceccato, Lundqvist, Abraham, Göransson \& Svennefelt) to Economy (Davanzo, Justus \& Ferro), yet fully engaged with existing criminology theories and state-of-theart literature. The special issue covers a variety of case studies, from Australia, Sweden, Slovenia, Brazil and United States. In the next section, we provide a brief discussion of these contributions to the field of rural criminology.

\section{Framing the Contributions to the Special Issue}

The first two articles share a common thread, namely they focus on animal rights but adopt complementary perspectives. With the increasing awareness of the environmental impact of consuming animal products, and growing recognition of animal rights and interest in veganism (Pendergrast, 2016), conflicts among animal rights activists and those who defend ethical animal production have also become more frequent. The first study by Pedersen \& White analyses the discourses featuring animal rights activism. Authors explore public narratives surrounding animal activism in Australia to suggest that the way that media, the public and farmers respond to animal activism depends upon the form or style of their actions, the focus of the activism, and the main protagonists involved. The second article is devoted to the nature of fear among farmers working with animal production as victims, based on responses from a national survey in Sweden. Ceccato, Lundqvist, Abraham, Göransson \& Svennefelt found that fear is greater among those farmers (their properties, families or employees) who have been previously victimized by animal activists, or experienced lack of support from the police, an issue that is exacerbated by geographical isolation. The third article focuses on the governance of water resources and crime written by Eman \& Meško. The study presents the importance of water governance and water-related issues in Slovenia from the perspectives of rural and green criminology. An extensive case study of the governance of water, water crimes, harmful policies, constitutional, and legislative changes based on referendums in Slovenia is presented in the article. The Slovenian government intended to present the Water Act to the Slovenian Parliament that included harmful provisions to the natural water resources and privatization of access to water in 2021. The reaction of civil and professional societies was strong and determined leading to a referendum. The referendum against the Water Act was hugely supported by $86.58 \%$ of the participating voters. The article emphasizes the importance of legislative changes that could cause harm to the people's quality of life and threaten sustainable development based on the protection of natural resources, and the power of a public referendum to prevent such impact. The next two studies are dedicated to gender violence in rural areas. Although violence against women is a global problem, international evidence shows that repeated and systematic intimate partner violence (IPV) is a particular problem in rural areas. In rural areas, women are less likely to report this kind of violence, for numerous reasons. For instance, long distances create isolation to a greater degree than in urban areas (Ceccato, 2015a, 2015b) but also lack of societal support are common denominators in rural areas that exacerbate the problem (DeKeseredy, 2015; DeKeseredy \& Joseph, 2006). The article by Strand, Selenius, Petersson \& Storey makes a contribution to the field of research by investigating how repeated and systematic intimate partner violence is handled by the criminal justice system in rural areas and how risk and victim vulnerability factors were related to recidivism using a sample of alleged perpetrators of repeated and systematic IPV who had been either reported or charged in Sweden. Interestingly, research has shown that females in rural contexts are more likely to experience dating violence victimization than peers in urban or suburban ones. The other article on gender violence is written by Liu, Beier \& Vazsonyi to assess the phenomenon of dating violence in a sample of adolescent girls located in the rural South of the United States. Authors found links between dating violence victimization and health problems of the victims such as depression, anxiety, and low self-esteem, and whether maternal peer approval conditioned this relationship. The final article is a case study from the Global South, more specifically about safety perceptions in Brazil. The study is written by Davanzo; Justus \& Ferro to investigate the nature of perceived safety experienced by individuals living in urban and in rural areas. The study analyses the effects of relative perceived safety (perception of neighbors) and indirect victimization (victimization of neighbors). The basic premise is that neighbors offer information to each other as they interact, affecting how individuals perceive safety. Results show that relative perceived safety affects an individual's perception of safety and that this effect varies across space, decreasing in more rural areas.

The authors and their research presented in this thematic issue are not only from Western countries but come from different continents and countries with different legal systems, different understandings of deviance, crime and traditions in criminological research. We believe that the sample of articles in this thematic issue can serve as examples for future research ideas in other country-contexts as they have potential to represent often missing or neglected perspectives of criminological research. Moreover, the articles are also in line with the United Nations Sustainable Development Goals SDGs), emphasizing the importance of care for living beings, natural resources, nonviolence and quality of life of people in general, especially in relation to goals of gender equality, clean water and 
sanitation, reduced inequalities, sustainable communities, responsible consumption and production, life on land, and peace justice and strong institutions (UNDP, n.d.).

One of the remaining challenges for future research in this area is to test the validity of traditional criminological theories to rural settings or outside of their original contexts. These articles are excellent examples of this kind of a research endeavor. Some of them are devoted to crime and/or fear in rural areas taking for granted the existence of a rural-urban divide but future research should embrace the idea that there are no sharp breaking points between rural and urban and explore nuances of a rural-urban continuum as part of object of study in its own right in rural criminology. Studying crime, harm and victimization on the rural-urban continuum demands further investigation by means of rigorous methods to produce sound empirical knowledge that can support crime prevention, mitigate harm and reduce fear of crime. The good news is that -as evidenced by the articles in this special issue-we have an increasing number of examples of a growing, exciting, international and interdisciplinary field of research, that makes use of the best of knowledge from various disciplines to tackle problems of global relevance.

For a selection of other articles on complementary topics in rural criminology with an international perspective, see the special issue in International Criminal Justice Review, forthcoming in 2022 composed of original research devoted to the processes of preparation of data, execution of research and analysis of crime and safety in rural areas, as well as those published outside the circle of criminological journals, such as the special issue in the Journal of Rural Studies in 2015. In addition, there are recent edited volumes in rural criminology, such as The Routledge International Handbook of Rural Criminology by Donnermeyer (2016) which provides an overview of the field so far and the most recent addition to the literature by Harkness (2020) on rural crime prevention.

Acknowledgements We are grateful to all the authors who contributed to this special issue. We would like to thank Editor-in-Chief Ineke Haen Marshall and the editorial board of International Criminology for welcoming the idea of this special issue. We also thank the editorial team of the journal and the anonymous referees for sharing their knowledge through their comments and suggestions. Five articles of this special issue were presented in sessions of the colloquium "Safety, resilience and community: Challenges and opportunities beyond the city" organized by KTH Safeplaces Network, Stockholm, Sweden that took place 29th September 2020. Thanks to the speakers and the participants of the colloquium that was partially funded by BRA-The Swedish National Crime Prevention Council. We would also like to thank universities in Sweden and the UK (Uppsala university, Plymouth University, Malmö University, Linköping University) which coorganized this online arena and the support of the international society for the study of rural crime (ISSRC).

\section{References}

Barclay, E., Donnermeyer, J. F., \& Jobes, P. C. (2004). The dark side of Gemeinschaft: Criminality within rural communities. Crime Prevention and Community Safety. https://doi.org/10.1057/palgr ave.cpcs.8140191

Ceccato, V. (2015a). Rural crime and community safety. Journal of Rural Studies, 39, 157-159. https://doi.org/10.1016/j.jrurstud. 2015.04.001

Ceccato, V. (2015). Violence against women in rural communities. In Rural crime and community safety (pp. 226-254). Routledge

Ceccato, V., \& Dolmen, L. (2011). Crime in rural Sweden. Applied Geography, 31(1), 119-135.

Chakraborti, N., \& Garland, J. (Eds.). (2011). Rural racism. Routledge.

DeKeseredy, W. S. (2015). New directions in feminist understandings of rural crime and social control. Journal of Rural Studies.

DeKeseredy, W. S., Donnermeyer, J. F., Schwartz, M. D., Tunnell, K., \& Hall, M. (2007). Thinking critically about rural gender relations: Toward a rural masculinity crisis/male peer support model of separation/divorce sexual assault. Critical Criminology, 15(4), 295-311. https://doi.org/10.1007/s10612-007-9038-0

DeKeseredy, W. S., \& Joseph, C. (2006). Separation and/or divorce sexual assault in rural Ohio: Preliminary results of an exploratory study. Violence against Women, 12(3), 301-311. https://doi.org/ $10.1177 / 1077801205277357$

Donnermeyer, J. F. (2016). The Routledge international handbook of rural criminology. Routledge.

Donnermeyer, J. F., \& DeKeseredy, W. S. (2013). Rural criminology. Routledge.

Favarin, S. (2020). New Methods to Enhance the Study of Environmental Crimes and New Instruments to Strengthen Crime Prevention. 36(3), 300-302. https://doi.org/10.1177/1043986220939705

Harkness, A. (Ed.). (2020). Rural crime prevention: Theory. Routledge.

Hillyard, P., \& Tombs, S. (2007). From 'crime' to social harm? Crime, Law and Social Change, 48(1), 9-25. https://doi.org/10.1007/ s10611-007-9079-Z

Meško, G. (2020). Rural criminology_A challenge for the future. European Journal of Crime, Criminal Law and Criminal Justice, 28(1), 3-13. https://doi.org/10.1163/15718174-02801001

Pendergrast, N. (2016). Environmental concerns and the mainstreaming of veganism. In R. T. M. Dora (Ed.), Impact of meat consumption on health and environmental sustainability (pp. 106-122). IGI Global.

Stassen, R., \& Ceccato, V. (2020). Environmental and wildlife crime (EWC) in Sweden 2000-2017. Journal of Contemporary Criminal Justice.

UNDP (n.d.). The SDGS in Action. https://www.undp.org/

Wakefield, A., \& Fleming, J. (2009). Responsibilization. In The SAGE Dictionary of Policing (pp. 276-278). Sage.

Wells, L. E., \& Weisheit, R. A. (2004). Patterns of rural and urban crime: A county-level comparison. Criminal Justice Review, 29(1), 1-22. https://doi.org/10.1177/073401680402900103

von Essen, E., Hansen, H. P., Källström, H., Peterson, N. M., \& Peterson, T. L. (2014). The radicalisation of a counterpublic: The case illegal hunting in the Nordic countries. Journal of Rural Studies, submitted.

Yarwood, R. (2001). Crime and policing in the British countryside: some agendas for contemporary geographical research. Sociologia Ruralis, 41(2), 201-219. https://doi.org/10.1111/1467-9523. 00178 